Prepared in cooperation with the U.S. Environmental Protection Agency

\title{
Assessment of Microscopic Pathology in Fishes Collected at Sites Impacted by Wood Tar in Pennsylvania
}

Open-File Report 2020-1024 



\section{Assessment of Microscopic Pathology in Fishes Collected at Sites Impacted by Wood Tar in Pennsylvania}

By Heather L. Walsh, Vicki S. Blazer, Patricia M. Mazik, Adam J. Sperry, and Diana Pavlick

Prepared in cooperation with the U.S. Environmental Protection Agency

Open-File Report 2020-1024 


\title{
U.S. Department of the Interior \\ DAVID BERNHARDT, Secretary
}

\author{
U.S. Geological Survey \\ James F. Reilly II, Director
}

U.S. Geological Survey, Reston, Virginia: 2020

For more information on the USGS - the Federal source for science about the Earth, its natural and living resources, natural hazards, and the environment—visit https://www.usgs.gov or call 1-888-ASK-USGS.

For an overview of USGS information products, including maps, imagery, and publications, visit https://store.usgs.gov/.

Any use of trade, firm, or product names is for descriptive purposes only and does not imply endorsement by the U.S. Government.

Although this information product, for the most part, is in the public domain, it also may contain copyrighted materials as noted in the text. Permission to reproduce copyrighted items must be secured from the copyright owner.

Suggested citation:

Walsh, H.L., Blazer, V.S., Mazik, P.M., Sperry, A.J., and Pavlick, D., 2020, Assessment of microscopic pathology in fishes collected at sites impacted by wood tar in Pennsylvania: U.S. Geological Survey Open-File Report 2020-1024, 14 p., https://doi.org/10.3133/ofr20201024.

ISSN 2331-1258 (online) 


\section{Acknowledgments}

This project was funded by the U.S. Environmental Protection Agency (EPA), Region 3, and by the U.S. Geological Survey's Environmental Health (Contaminant Biology) and Cooperative Fish and Wildlife Research Unit programs. The authors thank the EPA Wheeling office personnel for fish collections and associated field data. 



\section{Contents}

Acknowledgments ……...................................................................................................................

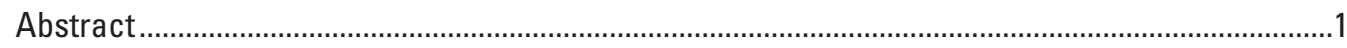

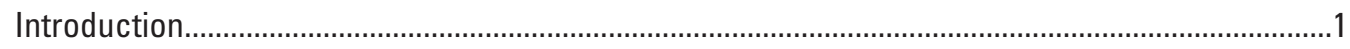

Methods

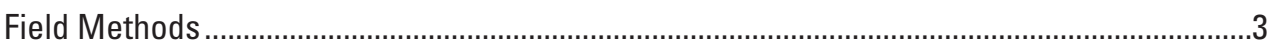

Histopathology

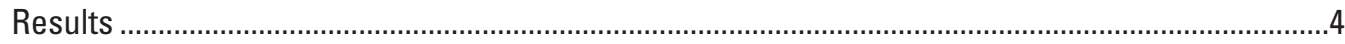

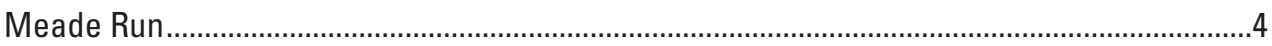

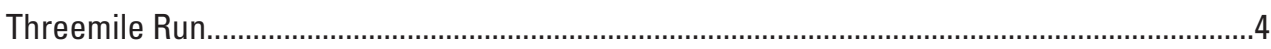

Kinzua Creek

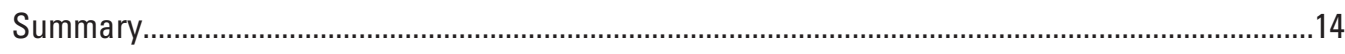

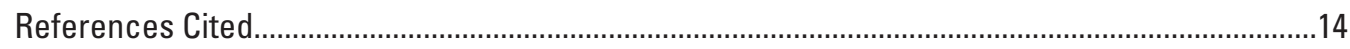

\section{Figures}

1. Maps showing fish collection sites on Kinzua Creek (KC), Threemile Run (TR), and Meade Run (BG), Pennsylvania ................................................................................

2. Microscopic observations in Redside Dace and Creek Chub collected at the Threemile Run upstream site (TR1) ...........................................................................

3. Microscopic observations in Common Shiner collected at the Mt. Alton site

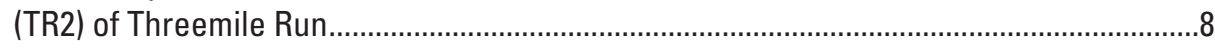

4. Microscopic observations in Creek Chub collected at Kinzua Creek ..............................11

\section{Tables}

1. Site information for fish collections at potential wood tar impacted sites ........................1

2. Summary of fish species, sample number, and visible abnormalities observed at

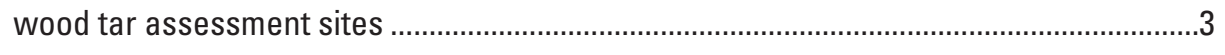

3. Meade Run (BG1) site Mottled Sculpin observations .......................................................

4. Observations of fish collected at the Threemile Run upstream site (TR1) ........................5

5. Observations of Common Shiner collected at the Threemile Run Mt. Alton

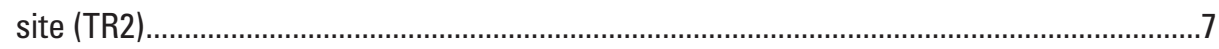

6. Threemile Creek Mt. Alton site (TR2) Western Blacknose Dace observations ..................9

7. Kinzua Creek upstream site (KC1) Western Blacknose Dace observations.....................10

8. Kinzua Creek upstream site (KC1) Creek Chub observations.........................................12

9. Kinzua Creek Backus site (KC2) Creek Chub observations ............................................13 


\section{Conversion Factors}

U.S. customary units to International System of Units

\begin{tabular}{lll}
\hline \multicolumn{1}{c}{ Multiply } & By & \multicolumn{1}{c}{ To obtain } \\
\hline inch (in.) & Length & \\
inch (in.) & 2.54 & centimeter (cm) \\
foot (ft) & 25.4 & millimeter (mm) \\
mile (mi) & 0.3048 & meter (m) \\
yard (yd) & 1.609 & kilometer (km) \\
& 0.9144 & meter (m) \\
\hline ounce, fluid (fl. oz) & Volume & \\
pint (pt) & 0.02957 & liter (L) \\
quart (qt) & 0.4732 & liter (L) \\
gallon (gal) & 0.9464 & liter (L) \\
\hline & 3.785 & liter (L) \\
\hline ounce, avoirdupois (oz) & Mass & \\
pound, avoirdupois (lb) & 28.35 & gram (g) \\
\hline
\end{tabular}

Temperature in degrees Celsius $\left({ }^{\circ} \mathrm{C}\right)$ may be converted to degrees Fahrenheit $\left({ }^{\circ} \mathrm{F}\right)$ as follows:

$$
{ }^{\circ} \mathrm{F}=\left(1.8 \times{ }^{\circ} \mathrm{C}\right)+32
$$

Temperature in degrees Fahrenheit $\left({ }^{\circ} \mathrm{F}\right)$ may be converted to degrees Celsius $\left({ }^{\circ} \mathrm{C}\right)$ as follows:

$$
{ }^{\circ} \mathrm{C}=\left({ }^{\circ} \mathrm{F}-32\right) / 1.8
$$

\section{Abbreviations}

BG1 Meade Run site

KC1 Kinzua Creek site

KC2 Backus Creek site

PAHs polycyclic aromatic hydrocarbons

TR1 Threemile Run site

TR2 Mt. Alton site 


\title{
Assessment of Microscopic Pathology in Fishes Collected at Sites Impacted by Wood Tar in Pennsylvania
}

\author{
By Heather L. Walsh, ${ }^{1}$ Vicki S. Blazer, ${ }^{1}$ Patricia M. Mazik, ${ }^{1}$ Adam J. Sperry, ${ }^{1}$ and Diana Pavlick²
}

\section{Abstract}

In an effort to determine whether fish populations in an area affected by wood tar waste exhibited health effects, fish were collected and analyzed with histopathology. Multiple species, including Mottled Sculpin (Cottus bairdii), Creek Chub (Semotilus atromaculatus), White Sucker (Catostumus commersonii), Redside Dace (Clinostomus elongatus), Common Shiner (Luxilus cornutus), and Western Blacknose Dace (Rhinichthys obtusus) were sampled from a reference site, Meade Run, and potentially affected streams, Kinzua Creek and Threemile Run, in northwestern Pennsylvania. A full histopathological evaluation was conducted to identify microscopic abnormalities potentially associated with wood tar exposure. The evaluation identified primarily parasites associated with tissue changes. These included microsporidian parasites in the ovaries of Common Shiner and Western Blacknose Dace; myxozoan cysts in the muscle of Common Shiner, Creek Chub, and Western Blacknose Dace; trematode cysts in the muscle of Creek Chub, Redside Dace and Common Shiner; and coccidia in spleen or pancreas of Creek Chub and Common Shiner. Microscopic abnormalities potentially associated with chemical exposure included ceroid/ lipofuscin deposits in the meninges of the olfactory lobe of the brain in Common Shiner, Western Blacknose Dace, and Creek Chub, as well as bile duct proliferation and a biliary tumor in
Creek Chub. Overall, the findings did not reveal significant microscopic pathology consistent with exposure to wood tar waste.

\section{Introduction}

Kinzua Creek is a 42.6-kilometer tributary of the Allegheny River in northwestern Pennsylvania. The former Day Chemical Company facility located in the area converted lumber to charcoal, methanol, and acetic acid. Wood tar is a tar-like waste generated by the chemical process and deposited into the ground. The material, which contains phenolic compounds and polycyclic aromatic hydrocarbons (PAHs), formed lagoons and flowed into the creek. Land use in the watershed is primarily forested with some residential area bordering the forests. Two sites (Mt. Alton and Backus) were identified by the U.S. Environmental Protection Agency (EPA) Region 3 Superfund Biological Technical Advisory Group for remediation of wood tar waste. The assessment plan was to sample fish for health-surveys from a site upstream from the Backus site on Kinzua Creek (KC1) and immediately below the impacted Backus site (KC2). Additionally, a site upstream from the Mt. Alton site on Threemile Run (TR1) and immediately below the Mt. Alton site (TR2) on Threemile Run were sampled. Meade Run (BG1), a tributary of Kinzua Creek not impacted by wood tar waste, was sampled as a reference (table 1; fig. 1).

${ }^{1}$ U.S. Geological Survey.

${ }^{2}$ West Virginia University.

Table 1. Site information for fish collections at potential wood tar impacted sites.

\begin{tabular}{cllcc}
\hline Site designation & \multicolumn{1}{c}{ Stream } & \multicolumn{1}{c}{ Site } & $\begin{array}{c}\text { Latitude } \\
\text { (decimal degrees) }\end{array}$ & $\begin{array}{c}\text { Longitude } \\
\text { (decimal degrees) }\end{array}$ \\
\hline BG 1 & Meade Run & Reference & 41.73869 & 78.78649 \\
TR 1 & Threemile Run & Upstream of Mt. Alton & 41.79409 & 78.62258 \\
TR 2 & Threemile Run & Mt. Alton & 41.78517 & 78.60868 \\
KC 1 & Kinzua Creek & Upstream of Backus & 41.81312 & 78.58243 \\
KC 2 & Kinzua Creek & Backus & 41.79850 & 78.57615 \\
\hline
\end{tabular}




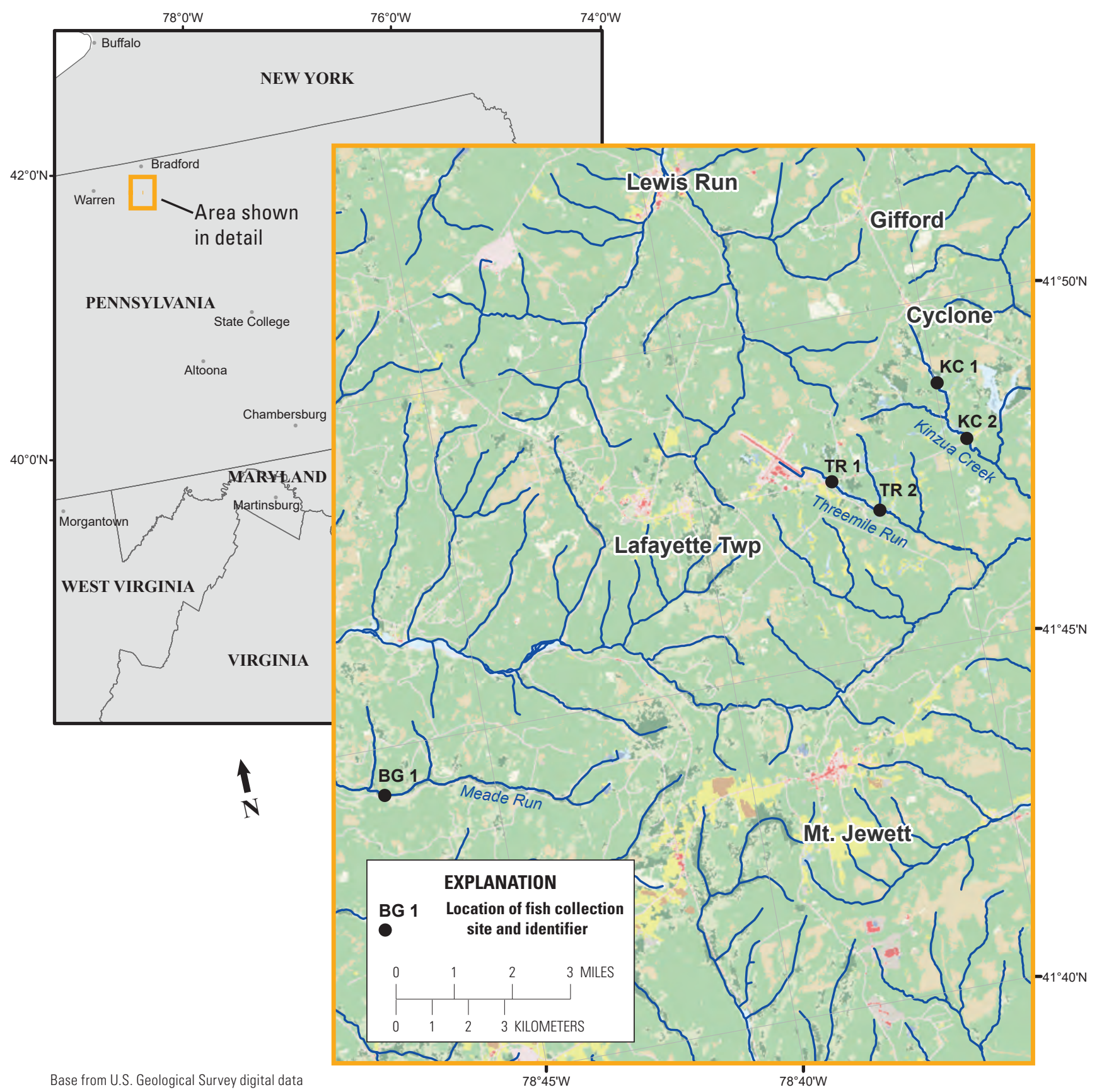

Figure 1. Fish collection sites on Kinzua Creek (KC), Threemile Run (TR), and Meade Run (BG), Pennsylvania. 


\section{Methods}

\section{Field Methods}

Sites were selected by EPA Region 3 and the fish were sampled by the EPA Freshwater Biology team from Wheeling, West Virginia. The incidence of deformities, fin erosion, lesions, and tumors (DELTs), as described by Sanders and others (1999), were documented. The EPA team preserved the fish in a 10-percent buffered formalin to be used for histopathological assessment. For the histopathology subsamples, as many as 30 random fish of the two most numerous species at each site were examined and preserved. The following species were collected for histopathology: Creek Chub (Semotilus atromaculatus), White Sucker (Catostumus commersonii), Common Shiner (Luxilus cornutus), Western Blacknose Dace (Rhinichthys obtusus), Mottled Sculpin (Cottus bairdii), and Redside Dace (Clinostomus elongatus). Individual species and sample sizes varied among sites (table 2). Preserved samples were transported to the U.S. Geological Survey Leetown Science Center. Total body lengths were only provided by the field crew for the Meade Run fishes.

\section{Histopathology}

Preserved samples were processed in two ways. If fish were small $(<10$ centimeters), whole fish were placed into decalcification solution (Thermo Scientific Richard-Allan Scientific Decalcifying Solution, ThermoFisher Scientific, Waltham, Mass.) for 1-3 days. Once decalcified, a cut was made behind the opercles to remove the head. The head was cut longitudinally into two pieces and placed into 1-2 cassettes. The tail area was removed, and the body cut longitudinally and both pieces placed in 1-2 cassettes depending on size. For larger fish, individual organs (liver, posterior and anterior kidney, spleen, heart, gills, any specific lesions) were removed.

Tissue samples were placed in cassettes, routinely processed through graded alcohols, and embedded into paraffin. Blocks were sectioned at 5 micrometers $(\mu \mathrm{m})$ and stained with hematoxylin and eosin (Luna, 1992). Slides were examined for any abnormalities at the microscopic level.

Table 2. Summary of fish species, sample number, and visible abnormalities observed at wood tar assessment sites.

[DELTs, deformities, fin erosions, lesions, or tumors]

\begin{tabular}{|c|c|c|c|c|}
\hline Site & Site designation & Species & $\begin{array}{l}\text { Total number of } \\
\text { individuals }\end{array}$ & $\begin{array}{l}\text { Number of fish } \\
\text { with DELTs }\end{array}$ \\
\hline Meade Run & BG 1 & Mottled Sculpin & 23 & 0 \\
\hline \multirow{2}{*}{ Threemile Creek upstream } & TR 1 & White Sucker & 1 & 1 \\
\hline & TR 1 & Redside Dace & 4 & 0 \\
\hline Threemile Creek Mt. Alton & TR 2 & White Sucker & 1 & 1 \\
\hline \multirow[t]{2}{*}{ Kinzua Creek upstream } & KC 1 & Western Blacknose Dace & 30 & 0 \\
\hline & $\mathrm{KC} 1$ & Creek Chub & 30 & 0 \\
\hline Kinzua Creek Backus & KC 2 & Creek Chub & 30 & 0 \\
\hline
\end{tabular}




\section{Results}

The same species were not consistently collected at both upstream and downstream sites or at the reference site. Species collected include Mottled Sculpin (BG1), White Sucker (TR1, TR2), Western Blacknose Dace (TR2, KC1), Creek Chub (TR1, KC1, KC2), and Common Shiner (TR2). Detailed information and histological findings are detailed by site below.

\section{Meade Run}

At the reference site, Meade Run (BG1), only Mottled Sculpin were collected on October 1, 2018, and preserved for histopathology. These were not collected at either Kinzua Creek or Threemile Run sites, making a true comparison to a reference site impossible. Nine male, 13 female, and 1 unidentified Mottled Sculpin, ranging in length from 50 to 115 millimeters, were collected. None were observed to have external abnormalities or significant internal lesions (table 3).

\section{Threemile Run}

Fish were sampled at two sites on Threemile Run on October 3, 2018, an upstream site (TR1) and the Mt. Alton impacted site (TR2). One White Sucker, 4 Redside Dace, and 27 Creek Chub were collected at TR1 (table 4).

At the upstream site (TR1), the White Sucker was noted as having a tumor by visual examination. Microscopically, no actual neoplasia was noted; however, there were some areas of epidermal hyperplasia. There were two male and two female Redside Dace collected; the ovaries of the females contained many atretic eggs (fig. $2 A$ ) with no obvious cause.

There were 13 female, 13 male, and 1 undetermined Creek Chub. Ovaries from two of the females had atretic eggs. All of the males were immature with undeveloped testes. One fish had coccidia parasites in the spleen (fig. 2B). Ceroid/ lipofuscin accumulations, indicative of oxidative damage, were present within the meninges of the olfactory lobe of the brain (fig. 2C) of 15 percent (4 out of 27) of the Creek Chub. The most common observation at this site was the presence of

Table 3. Meade Run (BG1) site Mottled Sculpin observations.

[F, female; M, male]

\begin{tabular}{|c|c|c|c|c|}
\hline Fish number & Length (millimeters) & Sex & External abnormalities & Microscopic observations \\
\hline BG1-1 & 115 & M & None & None \\
\hline BG1-2 & 105 & $\mathrm{~F}$ & None & None \\
\hline BG1-4 & 90 & M & None & None \\
\hline BG1-5 & 92 & $\mathrm{~F}$ & None & None \\
\hline BG1-7 & 84 & $\mathrm{~F}$ & None & None \\
\hline BG1-8 & 82 & M & None & None \\
\hline BG1-9 & 72 & M & None & None \\
\hline BG1-10 & 62 & M & None & None \\
\hline BG1-11 & 82 & Unknown & None & None \\
\hline BG1-15 & 61 & M & None & None \\
\hline BG1-16 & 64 & $\mathrm{~F}$ & None & None \\
\hline BG1-17 & 55 & $\mathrm{~F}$ & None & None \\
\hline BG1-18 & 52 & M & None & None \\
\hline BG1-19 & 66 & $\mathrm{~F}$ & None & None \\
\hline BG1-20 & 61 & $\mathrm{~F}$ & None & None \\
\hline BG1-21 & 52 & $\mathrm{~F}$ & None & None \\
\hline BG1-22 & 50 & $\mathrm{~F}$ & None & None \\
\hline
\end{tabular}


Table 4. Observations of fish collected at the Threemile Run upstream site (TR1).

[DELTs, deformities, fin erosions, lesions, or tumors; F, female; M, male; NG, no gonad]

\begin{tabular}{|c|c|c|c|c|c|}
\hline \multirow{2}{*}{$\begin{array}{c}\text { Fish } \\
\text { number }\end{array}$} & \multirow{2}{*}{ Species } & \multirow{2}{*}{ Sex } & \multirow{2}{*}{ External DELTs } & \multicolumn{2}{|c|}{ Microscopic observations } \\
\hline & & & & Trematode cysts & Other \\
\hline TR1-CC1 & White Sucker & F & Tumor & No & Epidermal hyperplasia \\
\hline TR1-CS1 & Redside Dace & M & None & Yes & None \\
\hline TR1-CS2 & Redside Dace & $\mathrm{F}$ & None & Yes & Atretic eggs, inflammation \\
\hline TR1-CS3 & Redside Dace & M & None & Yes & None \\
\hline TR1-CS4 & Redside Dace & $\mathrm{F}$ & None & Yes & Atretic eggs \\
\hline TR1-SA1 & Creek Chub & M & None & No & None \\
\hline TR1-SA2 & Creek Chub & $\mathrm{F}$ & Lesion & Yes & Erosion and inflammation \\
\hline TR1-SA3 & Creek Chub & $\mathrm{F}$ & None & Yes & Atretic eggs, inflammation \\
\hline TR1-SA4 & Creek Chub & M & None & Yes & None \\
\hline TR1-SA5 & Creek Chub & $\mathrm{F}$ & None & No & Brain ceroid \\
\hline TR1-SA6 & Creek Chub & $\mathrm{F}$ & None & No & None \\
\hline TR1-SA7 & Creek Chub & $\mathrm{F}$ & None & No & Brain ceroid \\
\hline TR1-SA8 & Creek Chub & M & None & No & Coccidia in spleen \\
\hline TR1-SA9 & Creek Chub & $\mathrm{F}$ & None & No & None \\
\hline TR1-SA10 & Creek Chub & M & None & Yes & None \\
\hline TR1-SA11 & Creek Chub & $\mathrm{F}$ & None & No & Brain ceroid \\
\hline TR1-SA12 & Creek Chub & $\mathrm{F}$ & None & No & None \\
\hline TR1-SA13 & Creek Chub & NG & None & No & None \\
\hline TR1-SA14 & Creek Chub & $\mathrm{F}$ & None & Yes & None \\
\hline TR1-SA15 & Creek Chub & M & None & No & None \\
\hline TR1-SA16 & Creek Chub & M & None & No & None \\
\hline TR1-SA17 & Creek Chub & M & None & Yes & None \\
\hline TR1-SA18 & Creek Chub & M & None & No & None \\
\hline TR1-SA19 & Creek Chub & M & None & No & None \\
\hline TR1-SA20 & Creek Chub & M & None & No & None \\
\hline TR1-SA21 & Creek Chub & M & None & No & None \\
\hline TR1-SA22 & Creek Chub & M & None & No & None \\
\hline TR1-SA23 & Creek Chub & $\mathrm{F}$ & None & No & None \\
\hline TR1-SA24 & Creek Chub & M & None & Yes & None \\
\hline TR1-SA25 & Creek Chub & M & None & Yes & None \\
\hline TR1-SA26 & Creek Chub & $\mathrm{F}$ & None & Yes & Brain ceroid, atretic eggs \\
\hline TR1-SA27 & Creek Chub & $\mathrm{F}$ & None & No & None \\
\hline
\end{tabular}




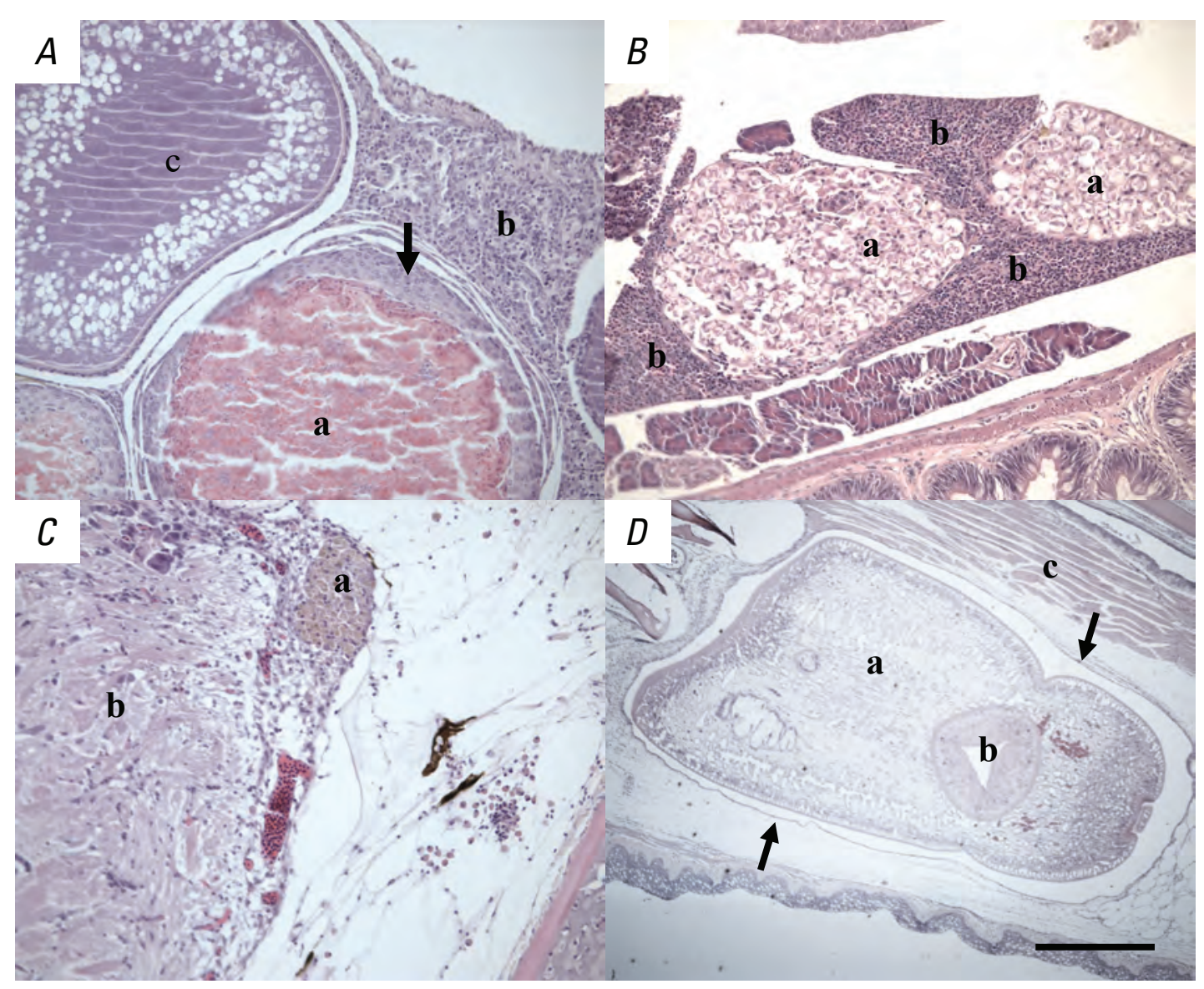

Figure 2. Microscopic observations in Redside Dace and Creek Chub collected at the Threemile Run upstream site (TR1). A. Ovarian tissue of Redside Dace with atretic eggs (a) with chronic inflammation within the oocyte (arrows) and in the surrounding tissue (b). Normal oocytes in the cortical alveolar stage (c) are present. Scale bar equals 50 micrometers $(\mu \mathrm{m})$. B. Coccidial parasites (a) within the spleen (b) of a Creek Chub. Scale bar equals $50 \mu \mathrm{m}$. C. Yellowish-brown ceroid/lipofuscin pigment (a) in the meninges of the olfactory lobe (b) of the brain of a Creek Chub. Scale bar equals $50 \mu \mathrm{m}$. D. Large trematode (a) with a sucker (b). located under the musculature (c) around the gills. The trematode is within a cyst (arrows). Scale bar equals $50 \mu \mathrm{m}$.

trematode cysts (fig. 2D). Encysted trematode metacercariae were present in all of the Redside Dace and 33 percent (9 out of 27) of the Creek Chub (table 4).

At the Mt. Alton site on Threemile Run (TR2), 1 White Sucker and 35 Common Shiner were collected on October 3, 2018. The White Sucker, a female, had a visible lesion that was microscopically identified as epidermal erosion with inflammation. No visible abnormalities were observed on the Common Shiners. All but two of the shiners were female (table 5).

Large encysted trematode metacercariae were observed in 23 percent ( 8 out of 35) of the Common Shiners, primarily in the musculature and connective tissue around the gills. The ovaries of 45 percent (15 out of 33) Common Shiners contained ovarian lesions, including atretic eggs and granulomatous inflammation in association with the presence of a microsporidian parasite within the oocytes (table 5). In some fish the majority of oocytes were normal with a few infected (fig. $3 A$ ); whereas in others the majority of the oocytes were infected (fig. 3B). The parasite location, appearance, and the inflammatory response induced (fig. $3 C$ ) were similar to Ovipleistophora ovariae (previously described as Pleistophora ovariae; Pekkarinen and others, 2002) reported from Golden Shiner, Notemigonus crysoleucas (Summerfelt, 1964). Ceroid/lipofuscin deposits in the olfactory lobe meninges were observed in 29 percent (10 out of 35) of the Common Shiners. Incidental findings included myxozoan cysts in the cartilage and gills of two fish, and coccidia in the spleen and pancreas of two fish (table 5).

Fourteen females, 13 males, and 3 unidentified Western Blacknose Dace were also collected at the Mt. Alton site (table 6). The most common finding (30 percent; 9 out of 30 ) was ceroid/lipofuscin deposits in the meninges of the olfactory lobe of the brain, similar to those observed in the Common Shiner (fig. 2C). Two of the ovaries also had atretic eggs with microsporidian parasites similar to the Common Shiner (fig. 3). 
Table 5. Observations of Common Shiner collected at the Threemile Run Mt. Alton site (TR2).

[F, female; M, male; NA, not applicable]

\begin{tabular}{|c|c|c|c|c|c|}
\hline \multirow{2}{*}{ Fish number } & \multirow{2}{*}{ Sex } & \multirow{2}{*}{$\begin{array}{c}\text { External } \\
\text { abnormalities }\end{array}$} & \multicolumn{3}{|c|}{ Microscopic observations } \\
\hline & & & Trematode cysts & Ovarian lesions 1 & Other \\
\hline TR2-LC1 & $\mathrm{F}$ & None & Yes & Yes & Myxozoan in cartilage \\
\hline TR2-LC2 & F & None & No & No & None \\
\hline TR2-LC3 & $\mathrm{F}$ & None & No & No & Inflammation around eye \\
\hline TR2-LC4 & $\mathrm{F}$ & None & Yes & Yes & Brain ceroid \\
\hline TR2-LC5 & $\mathrm{F}$ & None & No & No & None \\
\hline TR2-LC6 & F & None & No & No & Brain ceroid \\
\hline TR2-LC7 & F & None & No & Yes & Brain ceroid \\
\hline TR2-LC8 & $\mathrm{F}$ & None & No & Yes & Brain ceroid \\
\hline TR2-LC9 & F & None & Yes & Yes & Brain ceroid \\
\hline TR2-LC10 & F & None & Yes & Yes & None \\
\hline TR2-LC11 & F & None & No & No & Brain ceroid, coccidia in pancreas \\
\hline TR2-LC12 & $\mathrm{F}$ & None & No & No & Myxozoan cyst in gill \\
\hline TR2-LC13 & $\mathrm{F}$ & None & No & No & None \\
\hline TR2-LC14 & $\mathrm{F}$ & None & Yes & Yes & None \\
\hline TR2-LC15 & $\mathrm{F}$ & None & No & No & None \\
\hline TR2-LC16 & F & None & Yes & Yes & None \\
\hline TR2-LC17 & $\mathrm{F}$ & None & Yes & Yes & None \\
\hline TR2-LC18 & $\mathrm{F}$ & None & Yes & Yes & None \\
\hline TR2-LC19 & M & None & No & NA & None \\
\hline TR2-LC20 & M & None & No & NA & None \\
\hline TR2-LC21 & $\mathrm{F}$ & None & No & Yes & Coccidia in spleen \\
\hline TR2-LC22 & $\mathrm{F}$ & None & No & Yes & Brain ceroid \\
\hline TR2-LC23 & $\mathrm{F}$ & None & No & No & Brain ceroid \\
\hline TR2-LC24 & $\mathrm{F}$ & None & No & No & None \\
\hline TR2-LC25 & $\mathrm{F}$ & None & No & No & None \\
\hline TR2-LC26 & $\mathrm{F}$ & None & No & No & None \\
\hline TR2-LC27 & $\mathrm{F}$ & None & No & No & None \\
\hline TR2-LC28 & $\mathrm{F}$ & None & No & Yes & None \\
\hline TR2-LC29 & $\mathrm{F}$ & None & No & No & None \\
\hline TR2-LC30 & $\mathrm{F}$ & None & No & No & None \\
\hline TR2-LC31 & $\mathrm{F}$ & None & No & No & None \\
\hline TR2-LC32 & $\mathrm{F}$ & None & No & No & None \\
\hline TR2-LC33 & $\mathrm{F}$ & None & No & Yes & Brain ceroid \\
\hline TR2-LC34 & $\mathrm{F}$ & None & No & Yes & None \\
\hline TR2-LC35 & $\mathrm{F}$ & None & No & No & Brain ceroid \\
\hline
\end{tabular}

1 Ovarian lesions included atretic oocytes containing microsporidian parasites and associated inflammation. 


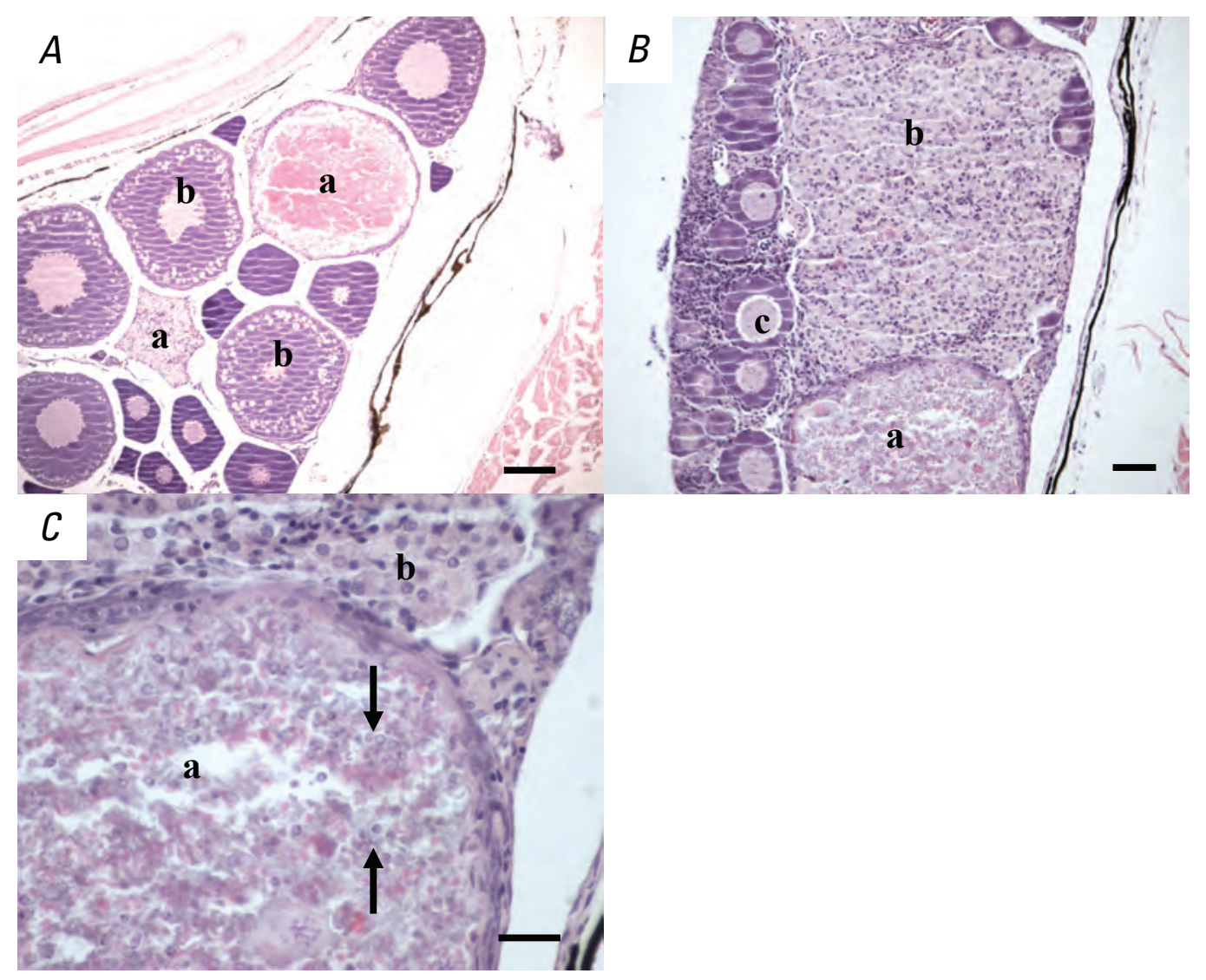

Figure 3. Microscopic observations in Common Shiner collected at the Mt. Alton site (TR2) of Threemile Run. A. Atretic oocytes (a) among the normal oocytes (b) within the ovary. Scale bar equals 10 micrometers $(\mu \mathrm{m})$. B. Oocytes (a) filled with microsporidian parasites Large areas of the ovary are replaced by chronic inflammatory response (b) with small areas of normal oocytes (c). Scale bar equals $50 \mu \mathrm{m}$. $C$. Higher magnification of an infected oocyte (a) illustrating the small microsporidian spores (arrows) and surrounding inflammation (b). Scale bar equals $20 \mu \mathrm{m}$.

\section{Kinzua Creek}

Twenty female and 10 male Western Blacknose Dace were collected at the upstream site on Kinzua Creek (KC1). Ceroid/lipofuscin deposits within the olfactory lobe meninges were observed in 17 percent (5 out of 30) of the individuals. Incidental findings included trematode and myxozoan cysts. Focal granulomas, indicative of a chronic inflammatory reaction, were noted in 27 percent ( 8 out of 30) of the Western Blacknose Dace from this site (table 7). The cause of this inflammatory reaction was not determined.

Thirteen female, 13 male, and 4 undetermined Creek Chub were collected at the upstream Kinzua Creek site. Small focal areas of inflammation of unknown etiology in the muscle (fig. $4 A$ ) or skin, myxozoan cysts in the muscle (fig. $4 B$ ), a cholangiocarcinoma (bile duct neoplasm; fig. $4 C$ ), and trematode cysts were observed (table 8).

At the Kinzua Creek Backus site (KC2), 8 male and 22 female Creek Chub were collected (table 9). Similar to Creek Chub collected at $\mathrm{KC} 1$, bile duct proliferation in the liver, myxozoan and trematode cysts, and inflammation in the muscle were observed. Additionally, brain ceroid was also observed in two individuals (7 percent) and pancreatic inflammation in two individuals. An unusual response was observed in the ovary of one fish, with microsporidian parasites within the oocytes where numerous rodlet cells were observed within the inflammation (fig. $4 D$ ). 
Table 6. Threemile Creek Mt. Alton site (TR2) Western Blacknose Dace observations.

[F, female; M, male; NG, no gonad]

\begin{tabular}{lll}
\hline Fish number & Sex & \\
\hline TR2-RA1 & F & Myxozoan cyst in gills \\
TR2-RA2 & F & Brain ceroid, gill trematode \\
TR2-RA3 & F & Brain ceroid \\
TR2-RA4 & F & Brain ceroid, atretic eggs with microsporidian \\
TR2-RA5 & M & None \\
TR2-RA6 & F & Brain ceroid, atretic eggs with microsporidian \\
TR2-RA7 & NG & Pancreatic inflammation \\
TR2-RA8 & M & None \\
TR2-RA9 & F & None \\
TR2-RA10 & F & None \\
TR2-RA11 & F & None \\
TR2-RA12 & M & Brain ceroid \\
TR2-RA13 & M & None \\
TR2-RA14 & F & Brain ceroid, epidermal hyperplasia with giant cells in skin \\
TR2-RA15 & M & Brain ceroid \\
TR2-RA16 & M & Brain ceroid \\
TR2-RA17 & M & Brain ceroid \\
TR2-RA18 & F & None \\
TR2-RA19 & M & None \\
TR2-RA20 & M & None \\
TR2-RA21 & F & Pancreatic inflammation \\
TR2-RA22 & F & None \\
TR2-RA23 & NG & None \\
TR2-RA24 & NG & None \\
TR2-RA25 & M & None \\
TR2-RA26 & F & None \\
TR2-RA27 & F & None \\
TR2-RA28 & M & None \\
TR2-RA29 & M & None \\
TR2-RA30 & M & None \\
& & \\
\hline
\end{tabular}


Table 7. Kinzua Creek upstream site (KC1) Western Blacknose Dace observations.

$[\mathrm{F}$, female; M, male]

\begin{tabular}{|c|c|c|}
\hline Fish number & Sex & Microscopic observations \\
\hline KC1-RA1 & $\mathrm{M}$ & None \\
\hline KC1-RA2 & $\mathrm{F}$ & Brain ceroid \\
\hline KC1-RA3 & $\mathrm{F}$ & Bile duct myxozoan \\
\hline $\mathrm{KC} 1-\mathrm{RA} 4$ & M & None \\
\hline KC1-RA5 & M & Brain ceroid \\
\hline KC1-RA6 & $\mathrm{F}$ & Focal inflammation in skin \\
\hline KC1-RA7 & M & Brain ceroid \\
\hline KC1-RA8 & M & Focal inflammation in muscle \\
\hline KC1-RA9 & $\mathrm{F}$ & Bile duct myxozoan \\
\hline KC1-RA10 & M & Brain ceroid \\
\hline KC1-RA11 & $\mathrm{F}$ & None \\
\hline KC1-RA12 & $\mathrm{F}$ & None \\
\hline KC1-RA13 & $\mathrm{F}$ & None \\
\hline KC1-RA14 & $\mathrm{F}$ & Focal inflammation in muscle \\
\hline KC1-RA15 & $\mathrm{F}$ & Brain ceroid, focal inflammation in fin \\
\hline KC1-RA16 & $\mathrm{F}$ & None \\
\hline KC1-RA17 & $\mathrm{F}$ & None \\
\hline KC1-RA18 & $\mathrm{F}$ & None \\
\hline KC1-RA19 & M & None \\
\hline KC1-RA20 & $\mathrm{F}$ & Focal inflammation in muscle \\
\hline KC1-RA21 & $\mathrm{F}$ & None \\
\hline KC1-RA22 & $\mathrm{F}$ & None \\
\hline KC1-RA23 & M & None \\
\hline KC1-RA24 & $\mathrm{F}$ & None \\
\hline KC1-RA25 & $\mathrm{F}$ & Focal inflammation in muscle \\
\hline KC1-RA26 & $\mathrm{F}$ & None \\
\hline KC1-RA27 & M & None \\
\hline KC1-RA28 & M & Focal inflammation in muscle \\
\hline KC1-RA29 & $\mathrm{F}$ & None \\
\hline KC1-RA30 & $\mathrm{F}$ & Focal inflammation in skin \\
\hline
\end{tabular}




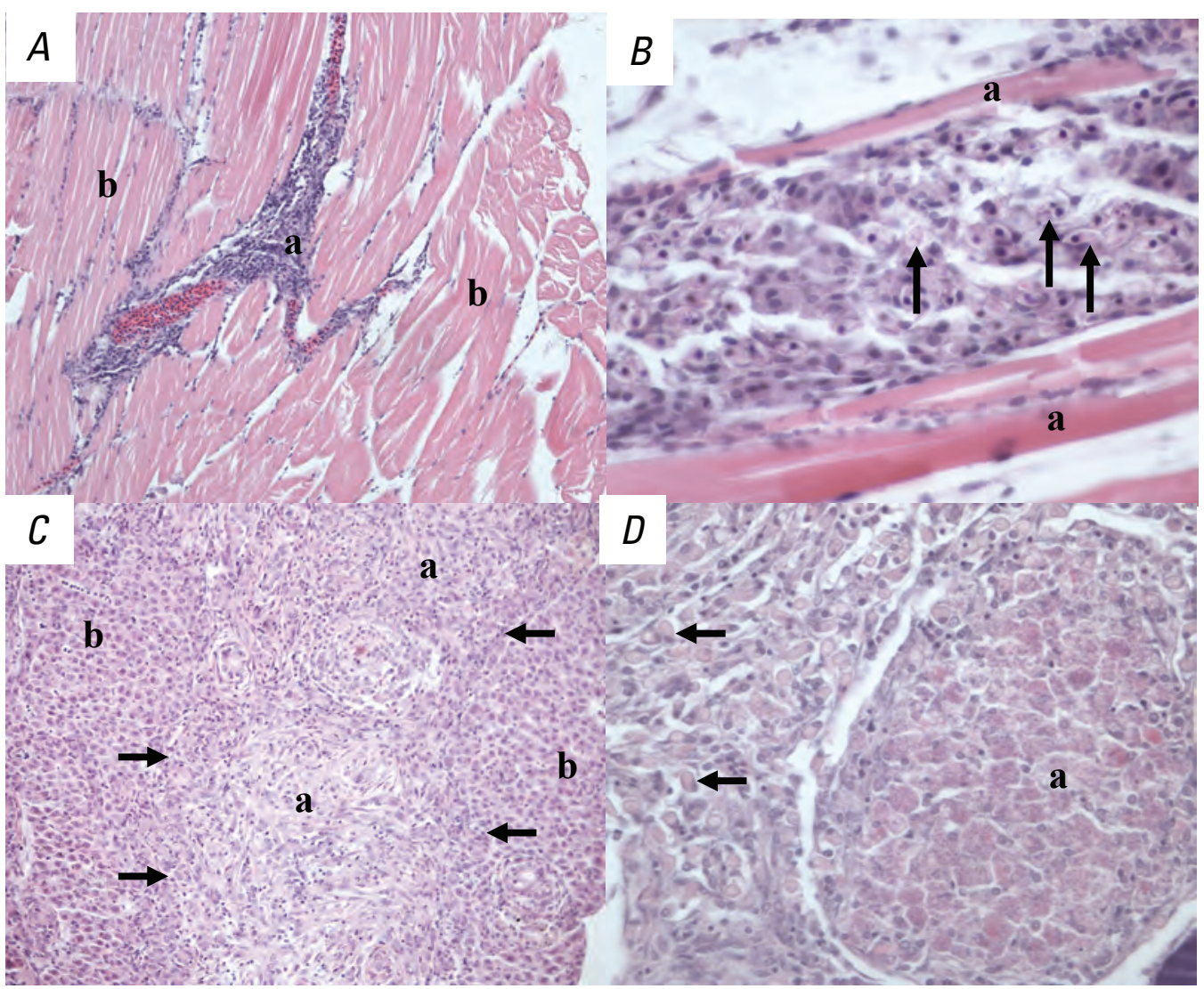

Figure 4. Microscopic observations in Creek Chub collected at Kinzua Creek. A. Focal areas of acute inflammation (a) around the skeletal muscle bundles (b). Scale bar equals 50 micrometers $(\mu \mathrm{m})$. B. Myxozoan spores (arrows) within a muscle bundle (a). Scale bar equals $20 \mu \mathrm{m}$. $C$. Cholangiocarcinoma (a) composed of disorganized, proliferating bile ducts separated from surrounding hepatic tissue (b) by a poorly defined border (arrows) was observed at the upstream site (KC1). Scale bar equals $50 \mu \mathrm{m}$. D. Microsporidian parasites infecting oocytes (a), surrounded by inflammation with the presence of rodlet cells (arrows) were observed at the Backus (KC2) site. Scale bar equals $30 \mu \mathrm{m}$. 


\section{Assessment of Microscopic Pathology in Fishes Collected at Sites Impacted by Wood Tar in Pennsylvania}

Table 8. Kinzua Creek upstream site (KC1) Creek Chub observations.

[F, female; M, male; NG, no gonad]

\begin{tabular}{|c|c|c|}
\hline Fish number & Sex & Microscopic observations \\
\hline KC1-SA1 & $\mathrm{M}$ & None \\
\hline KC1-SA2 & $\mathrm{F}$ & Inflammation in skin \\
\hline $\mathrm{KC} 1-\mathrm{SA} 3$ & $\mathrm{~F}$ & None \\
\hline $\mathrm{KC} 1-\mathrm{SA} 4$ & M & None \\
\hline KC1-SA5 & M & Trematode cysts in muscle \\
\hline KC1-SA6 & M & None \\
\hline $\mathrm{KC} 1-\mathrm{SA} 7$ & F & None \\
\hline $\mathrm{KC} 1-\mathrm{SA} 8$ & M & None \\
\hline KC1-SA9 & $\mathrm{F}$ & Muscle myxozoan \\
\hline KC1-SA10 & NG & None \\
\hline KC1-SA11 & $\mathrm{F}$ & Inflammation in muscle \\
\hline KC1-SA12 & F & Trematode cysts in muscle \\
\hline KC1-SA13 & M & Inflammation in muscle, myxozoan cysts \\
\hline KC1-SA14 & M & Cholangiocarcinoma \\
\hline KC1-SA15 & $\mathrm{M}$ & Muscle myxozoan \\
\hline KC1-SA16 & F & None \\
\hline KC1-SA17 & M & None \\
\hline KC1-SA18 & M & None \\
\hline KC1-SA19 & NG & None \\
\hline KC1-SA20 & $\mathrm{F}$ & None \\
\hline KC1-SA21 & NG & None \\
\hline KC1-SA22 & NG & None \\
\hline KC1-SA23 & M & None \\
\hline $\mathrm{KC} 1-\mathrm{SA} 24$ & $\mathrm{~F}$ & Inflammation in muscle \\
\hline KC1-SA25 & $\mathrm{F}$ & Bile duct proliferation \\
\hline KC1-SA26 & M & None \\
\hline KC1-SA27 & F & None \\
\hline $\mathrm{KC} 1-\mathrm{SA} 28$ & $\mathrm{~F}$ & Inflammation in muscle \\
\hline $\mathrm{KC} 1-\mathrm{SA} 29$ & F & Ovarian atresia with inflammation \\
\hline KC1-SA30 & $\mathrm{M}$ & None \\
\hline
\end{tabular}


Table 9. Kinzua Creek Backus site (KC2) Creek Chub observations.

[F, female; M, male]

\begin{tabular}{|c|c|c|}
\hline Fish number & Sex & Microscopic observations \\
\hline KC2-SA1 & $\mathrm{F}$ & None \\
\hline KC2-SA2 & $\mathrm{F}$ & None \\
\hline $\mathrm{KC} 2-\mathrm{SA} 3$ & M & Brain ceroid \\
\hline $\mathrm{KC} 2-\mathrm{SA} 4$ & $\mathrm{~F}$ & Pancreatic inflammation, bile duct proliferation \\
\hline KC2-SA5 & M & Trematode cyst \\
\hline KC2-SA6 & $\mathrm{F}$ & Pancreatic inflammation \\
\hline $\mathrm{KC} 2-\mathrm{SA} 7$ & M & None \\
\hline KC2-SA8 & $\mathrm{F}$ & None \\
\hline KC2-SA9 & $\mathrm{F}$ & Myxozoan in muscle \\
\hline $\mathrm{KC} 2-\mathrm{SA} 10$ & $\mathrm{~F}$ & Inflammation in muscle \\
\hline KC2-SA11 & $\mathrm{F}$ & None \\
\hline KC2-SA12 & $\mathrm{F}$ & None \\
\hline KC2-SA13 & M & Brain ceroid \\
\hline KC2-SA14 & M & None \\
\hline KC2-SA15 & M & None \\
\hline KC2-SA16 & $\mathrm{F}$ & None \\
\hline KC2-SA17 & $\mathrm{F}$ & Atretic eggs, inflammation and rodlet cells in ovary \\
\hline KC2-SA18 & $\mathrm{F}$ & None \\
\hline KC2-SA19 & $\mathrm{F}$ & None \\
\hline $\mathrm{KC} 2-\mathrm{SA} 20$ & $\mathrm{~F}$ & None \\
\hline $\mathrm{KC} 2-\mathrm{SA} 21$ & M & None \\
\hline $\mathrm{KC} 2-\mathrm{SA} 22$ & $\mathrm{~F}$ & None \\
\hline $\mathrm{KC} 2-\mathrm{SA} 23$ & $\mathrm{~F}$ & None \\
\hline $\mathrm{KC} 2-\mathrm{SA} 24$ & $\mathrm{~F}$ & Myxozoan in cartilage \\
\hline $\mathrm{KC} 2-\mathrm{SA} 25$ & $\mathrm{~F}$ & None \\
\hline $\mathrm{KC} 2-\mathrm{SA} 26$ & $\mathrm{~F}$ & None \\
\hline $\mathrm{KC} 2-\mathrm{SA} 27$ & $\mathrm{~F}$ & Trematode cyst \\
\hline $\mathrm{KC} 2-\mathrm{SA} 28$ & $\mathrm{~F}$ & None \\
\hline KC2-SA29 & M & None \\
\hline $\mathrm{KC} 2-\mathrm{SA} 30$ & $\mathrm{~F}$ & None \\
\hline
\end{tabular}




\section{Summary}

The majority of microscopic abnormalities observed in this study were related to parasitic infections. There were virtually no observable differences in types and severity of parasitic infections and host responses between fish of the same species sampled at the upstream sites and at the impacted sites. The other commonly observed abnormality, ceroid/lipofuscin deposits within the meninges of the olfactory lobe, was also observed in fish collected at both impacted and upstream sites. Although the incidence at the impacted sites was higher, the species of fish was not the same, which confounds the findings. The cause of this type of lesion, an accumulation of autofluorescent chromolipids, is unknown. Lipofuscins have traditionally been considered accumulations of polymerized lipid material associated with aging, whereas ceroids are considered a pathological accumulation of polymerized or oxidized lipid (Porta and others, 2002; Seehafer and Pearce, 2006). A variety of contaminants and other environmental stressors can cause oxidative stress in fish (Srivastava and Reddy, 2017).

Microsporidia, myxozoan, and trematode parasites were observed in numerous fish in this study. The significance of these findings on the health of these fish populations is unknown. Parasitic infections in fish have been used as an indication of environmental health (Marcogliese, 2005) and there are environmental variables such as temperature, contaminants, stream drift, and water quality that affect parasite assemblages in fish (Landsberg and others, 1998; BlascoCosta and others, 2013). In this study, females with microsporidia infections in their ovaries exhibited a mild to severe inflammatory response and had atretic oocytes. However, the effect of these infections on reproductive health remains unknown. Myxozoan and trematode cysts, on the other hand, were observed mainly in the muscle and initiated minimal host response. In order to fully understand the impact of these parasites and pathogens on the fish sampled from Kinzua Creek and its tributaries, long-term monitoring would need to be considered in order to understand what types and severity of infections are considered normal for these fish populations.

To conclude, there was minimal evidence that the fish in this study responded to contaminants in the wood tar waste at the affected sampling sites. However, histopathology alone may not be an effective tool for analyzing the effects of exposure. In fish, molecular dysfunction, growth inhibition, and behavioral and reproductive effects could occur without histopathological changes.

\section{References Cited}

Blasco-Costa, I., Koehler, A.V., Martin, A., and Poulin, R., 2013, Upstream-downstream gradient in infection levels by fish parasites - A common river pattern?: Parasitology, v. 140 , no. 2, p. 266-274, accessed October 23, 2019, at https://doi.org/10.1017/S0031182012001527.
Landsberg, J.H., Blakesley, B.A., Reese, R.O., Mcrae, G., and Forstchen, P.R., 1998, Parasites of fish as indicators of environmental stress: Environmental Monitoring and Assessment, v. 51, no. 1/2, p. 211-232, accessed November 10, 2019, at https://doi.org/10.1023/ A:1005991420265.

Luna, L.G., 1992, Histopathologic methods and color atlas of special stains and tissue artifacts: Gaithersburg, Md., American Histolabs, Inc., 767 p.

Marcogliese, D.J., 2005, Parasites of the superorganismAre they indicators of ecosystem health?: International Journal for Parasitology, v. 35, no. 7, p. 705-716, accessed November 10, 2019, at https://doi.org/10.1016/ j.ijpara.2005.01.015.

Pekkarinen, M., Lom, J., and Nilsen, F., 2002, Ovipleistophora gen. n., a new genus for Pleistophora mirandellae-like microsporidia: Diseases of Aquatic Organisms, v. 48, p. 133-142, accessed November 14, 2019, at https://doi.org/ 10.3354/dao048133.

Porta, E.A., Berra, A., Monserrat, A.J., and Benavides, S.H., 2002, Differential lectin histochemical studies on lipofuscin (age-pigment) and on selected ceroid pigment: Archives of Gerontology and Geriatrics, v. 34, no. 3, p. 193-203, accessed November 11, 2019, at https://doi.org/10.1016/ S0167-4943(01)00224-2.

Sanders, R.E., Miltner, R.J., Yoder, C.O., and Rankin, E.T., 1999, The use of external deformities, erosions, lesions, and tumors (DELT anomalies) in fish assemblages for characterizing aquatic resources - A case study of seven Ohio streams, in Simon, T.P., ed., Assessing the Sustainability and Biological Integrity of Water Resources Using Fish Communities: Boca Raton, Fla., CRC Press, p. 225-2248.

Seehafer, S.S., and Pearce, D.A., 2006, You say lipofuscin, we say ceroid-Defining autofluorescent storage material: Neurobiology of Aging, v. 27, no. 4, p. 576-588, accessed November 11, 2019, at https://doi.org/10.1016/ j.neurobiolaging.2005.12.006.

Srivastava, B., and Reddy, P.B., 2017, Lipid peroxidation and DNA damage as biomarkers of pollution induced oxidative stress (OS) in fish: Life Sciences International Journal, v. 4, p. 194-198, accessed November 14, 2019, at https://doi.org/10.13140/RG.2.2.13114.80323.

Summerfelt, R.C., 1964, A new microsporidian parasite from the golden shiner, Notemigonus crysoleucus: Transactions of the American Fisheries Society, v. 93, no. 1, p. 6-10, accessed November 11, 2019, at https://doi.org/10.1577/ 1548-8659(1964)93[6:ANMPFT]2.0.CO;2. 
For more information, contact

Director, Leetown Science Center

U.S. Geological Survey

11649 Leetown Road

Kearneysville, WV 25430

Publishing support provided by the West Trenton and Pembroke Publishing Service Centers 
